DOI: $10.15393 /$ j10.art.2019.3801

УДК 821.161 .1

\title{
Стефано Алоэ
}

PhD, доиент-исследователь по русской литературе, вице-президент Международного общества Достоевского, Университет Вероны

(Верона, Италия)

stefano.aloe@univr.it

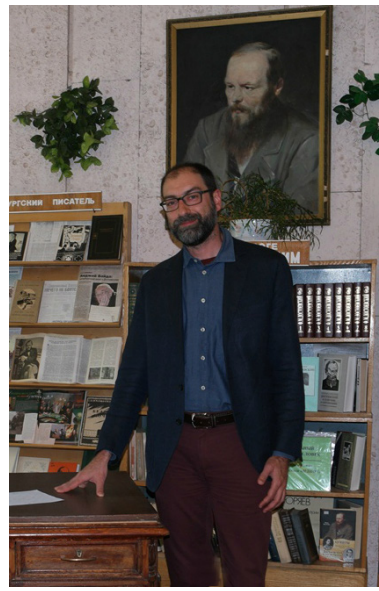

\section{Италия в биографии Ф. М. Достоевского: \\ Нескодько вводных заметок по поводу архивных находок Вадентины Супино}

Аннотация. Роль Италии в жизни и творчестве Ф. М. Достоевского бесспорно велика, несмотря на недолгое время, проведенное им в этой стране. Писатель посещал Италию три раза: в 1862, 1863 и 1868-1869 гг.; каждое путешествие имело свое особое значение в его творческой и личной биографии. Его увлечение Италией с юности вызвано как множеством культурных интересов: к ренессансной живописи, к итальянской опере, к античной истории, - так и вниманием к политической обстановке в стране, к религиозным вопросам, связанным с «вечным городом» Римом и с католицизмом. Тем не менее связи Достоевского с Италией не стали до сих пор предметом отдельных комплексных исследований, а некоторые факты его пребывания в этой стране остаются неустановленными. Настоящие заметки ставят ряд вопросов, посвященных биографическим исследованиям об итальянских периодах жизни писателя, и являются введением к статье В. Супино, исследовательницы биографии Достоевского, которая приводит ранее не известные данные о периоде проживания писателя во Флоренции в 1868-1869 гг.

Ключевые слова: Ф. М. Достоевский, Италия, Флоренция, Католицизм и Православие, итальянская достоевистика

$\mathrm{H}$ есмотря на непродолжительность пребывания Ф. М. Достоевского в Италии, роль этой страны в творческой и личной биографии писателя бесспорно велика. Многое в итальянской культуре привлекало Достоевского: он любил ренессансное искусство (в особенности живопись Рафаэля), в молодости в Петербурге был завсегдатаем оперных театров, в которых прежде всего ценил итальянскую оперу (его любимым композитором был Джоаккино Россини), интересовался вопросами истории и политики Италии и остро критически, но со страстным вниманием, относился к католичеству, во многом связанному с «вечным городом» Римом и духом и обычаями Апеннинского полуострова. 
Как известно, Достоевский посещал Италию трижды. Впервые он побывал там в 1862 г. вместе с Н. Н. Страховым (через Турин, Геную и Ливорно они прибыли во Флоренцию в начале августа, через десять дней они расстались, и Достоевский возвратился в Россию через Милан, Венецию, Вену и Дрезден) [Кара-Мурза, 2001: 63-82].

Второе короткое путешествие в Италию связано с бурным романом писателя с Аполлинарией Сусловой, вместе с которой Достоевский в 1863 г. посетил Рим, Неаполь, Ливорно и Турин.

Самое продолжительное пребывание писателя в Италии началось в сентябре 1868 г., когда он со второй женой Анной Григорьевной приехал из Швейцарии в Милан через Симплон и Домодоссола. В конце ноября они отправились во Флоренцию, в тот период уже ставшую столицей Италии, где остановились надолго - до начала августа 1869 г. Там Достоевский завершил работу над романом «Идиот», задумал новый роман с изначальным названием «Атеизм» (далее - «Житие великого грешника»). В первые дни августа 1869 г. писатель с женой и тещей А. Н. Сниткиной перебирается в Дрезден через Венецию, Триест, Вену и Прагу.

Каждое из этих трех путешествий уникально и представляет собой важный этап жизненного пути писателя.

Об отдельных аспектах жизни и творчества Достоевского в Италии написано много. Однако исчерпывающие исследования о связях писателя с Италией и итальянской культурой в целом отсутствуют. Этот факт объясняется разными причинами. Одна их них состоит в небольшом количестве сохранившихся биографических данных о его путешествиях по Италии. Итальянская тема представлена в письмах, записных книжках и творческих тетрадях, художественных и публицистических произведениях Достоевского, но отсутствуют описательные подробности местной жизни.

О его третьем и самом длительном периоде пребывания в Италии (18681869 гг.) известно в основном по воспоминаниям А. Г. Достоевской, а также по поздним мемуарам дочери писателя Любови Федоровны. Если учитывать характерный для него «мизанабим» (от фр. mise en abyme - «помещение в бездну», встраивание внутрь) всего автобиографического, которое скрывается в сюжетах его художественных произведений и часто доведено до неузнаваемости. По этой же причине уточнение любой биографической детали из жизни Достоевского является особо ценным в плане изучения его творческого мира - это может открыть новые грани понимания персонажей и сюжетов романов и рассказов писателя.

Статья Валентины Супино, публикуемая в настоящем номере журнала «Неизвестный Достоевский», раскрывает ряд доныне неизвестных деталей о жизни писателя во Флоренции с конца 1868 г. по август 1869 г. Это стало возможным благодаря находкам, сделанным автором статьи в архивах приходских церквей, неподалеку от которых писатель проживал. Несмотря на то, что не все 
гипотезы г-жи Супино доказуемы, ее исследовательская работа дает ценный материал для пересмотра некоторых аспектов творческой биографии писателя, в особенности в связи с возникшим во флорентийский период замыслом романа «Атеизм» и последующими главными произведениями Федора Михайловича. В статье г-жи Супино рассматривается один из эпизодов жизни Достоевского в Италии, который предоставляет новые факты неоднозначного отношения писателя к католицизму.

Валентина Супино происходит из известной семьи флорентийской интеллигенции. В юности она переехала в Париж, где окончила университет, вышла замуж и работала по специальности. И в настоящее время, выйдя на пенсию, она проживает в Париже, но каждое лето возвращается во Флоренцию в семейный дом [Mascagni, 2018: 82-83]. По профессии она - врачпсихиатр и психоаналитик, является автором ряда научных книг и статей на такие темы, как депрессия, эпилепсия, детские психологические травмы, в которых эпизоды из жизни и произведений Достоевского приводятся в качестве примеров изучаемых патологий. Темы научных исследований В. Супино, по ее признанию, косвенно связаны с проблемами подросткового возраста в творчестве Достоевского, которое она всю жизнь изучала с точки зрения психиатра. В своих работах особенное внимание В. Супино уделила той части биографии писателя, которая связана с его пребыванием в Западной Европе и, в частности, во Флоренции. Первым результатом разысканий на эту тему стала небольшая монография на итальянском языке, вышедшая в двух изданиях: Supino V. I soggiorni di Dostoevskij in Europa e la loro influenza sulla sua opera. 2a edizione. Firenze: LoGisma, 2017 (Пер.: Сyпино В. Пребывание Достоевского в Европе и ее влияние на его произведения. 2-е изд. Флоренция: Логизма, 2017). Свои последующие архивные находки автор опубликовала в статье «Флорентийские адреса Достоевского». Не являясь литературоведом, В. Супино имеет успехи в архивных разысканиях, и это обещает выявление новых материалов для уточнения жизненных перипетий Достоевского в Европе.

Работа В. Супино продолжает ряд исследований, которые в последние годы несколько расширили и уточнили сведения о двух посещениях Достоевским Флоренции в августе 1862 и в 1868-1869 гг.

Архивные находки во Флоренции начались с открытия трех абонементных записей Достоевского в «Кабинете Вьёссё», о которых писала сначала К. Стрельская [Strelsky, 1964: 149-163], а позже Н. П. Прожогин [Прожогин, 1981, 1983]. Архивная работа в «Кабинете Вьёссё» ведется до сих пор, ее результаты представлены, в частности, в работах Л. Тонини [Tonini, 2000: 2746], [Тонини, 2016: 329-342]. В свое время нами были изучены архивные материалы, связанные с деятельностью во Флоренции литератора и журналиста Анджело де Губернатиса и касающиеся первого отклика в Италии на произведения Достоевского [Aloe, 2000], [Алоэ, 2000]. Несмотря на то, 
что дом де Губернатиса во Флоренции во второй половине XIX в. посещали многочисленные русские литераторы (в том числе И. С. Тургенев, М. А. Бакунин, А. Н. Веселовский, А. К. Толстой, Ф. И. Буслаев и др.), свидетельств, подтверждающих знакомство Достоевского с этим активным прорусским итальянским деятелем культуры, нет. Тем не менее, по прихоти судьбы, первая журнальная статья о Достоевском в Италии, сопровождающая перевод одной из глав романа «Преступление и наказание», была опубликована де Губернатисом в августе 1869 г., именно в то время, когда Федор Михайлович навсегда оставил Флоренцию.

К упомянутым работам нужно прибавить недавно появившиеся публикации В. Н. Захарова о сотруднике журнала «Эпоха» Сергее Колошине, умершем во Флоренции 27 ноября 1868 г. [Захаров, 2013: 58-61] и о судебном розыске Достоевского летом 1871 г. во Флоренции [Захаров, 2012: 276-277].

Все эти исследования свидетельствуют о том, что архивные поиски могут раскрыть еще много интересного о жизни и деятельности Достоевского в Италии, связанного не только с его пребыванием во Флоренции между 1868 и 1869 гг., - но не исключены находки и в Милане, Венеции, Неаполе и других городах, в которых писатель останавливался даже на самое непродолжительное время (ср. попытку изучения краткосрочного посещения писателем Болоньи у Д. Гини [Ghini, 1995]).

На сегодняшний день остается много лакун, не позволяющих реконструировать в полной мере жизнь Достоевского в Италии. Почти ничего не известно о том, с кем он виделся, были ли у него итальянские знакомые и приятели, встречался ли он с русскими, проживавшими в итальянских городах. Отметим, что в последние годы появилось несколько монографий, многое проясняющих о жизни русских в тогдашней столице Италии [Meloni Trkulja, 1996: 251-260], [Ризалити, 2011], [Garzaniti, 2013: 285-295], [Талалай, 2014]. Однако подробно почти не изучены русская «колония» и пребывание русских путешественников во Флоренции и других городах Италии. Например, мы мало что знаем о русском православном священнике, действовавшем, вероятно, при консульстве России во Флоренции (см.: [Талалай, 2004-2005]), или о самих консулах и послах России того времени (графах Николае Киселеве и Алексее Зубове). Государственные, приходские, полицейские архивы Италии (тех городов, где они уцелели после исторических и, в частности, военных катастроф) еще могут дать новые сведения о пребывании Достоевского в этой стране. 


\section{СПИСОК ЛИТЕРАТУРЫ}

1. Алоэ С. Первые этапы знакомства с Ф. М. Достоевским в Италии // Достоевский и мировая культура. Альманах № 15. - СПб., 2000. - С. 141-155.

2. Захаров В. Н. Судебный розыск Достоевского летом 1871 г. // Достоевский и мировая культура. Альманах № 29. - СПб., 2012. - С. 276-277.

3. Захаров В. Н. Неопубликованный автограф Достоевского: Ф. М. Достоевский и С. П. Колошин // Ученые записки Петрозаводского государственного университета. Сер.: Общественные и гуманитарные науки. - 2013. — № 7 (136). — Т. 2. - С. 58-61.

4. Кара-Мурза А. А. Знаменитые русские о Флоренции. - М.: Независимая газета, 2001. C. $63-82$.

5. Прожогин Н. П. Достоевский во Флоренции // Иностранная литература. - 1981. № 8. - С. 237-244.

6. Прожогин Н. П. Достоевский во Флоренции в 1868-1869 гг. // Достоевский. Материалы и исследования. - Л.: Наука, 1983. - Т. 5. - С. 204-208.

7. Ризалити Р. Русская Тоскана. Статьи разных лет о русских в Тоскане и тосканцах в России. - СПб.: Алетейя, 2011. - 192 с.

8. Талалай М. Русская Православная Церковь во Флоренции // Россия в красках. - Зима 2004-2005. — № 1 [Электронный ресурс]. — URL: http://ricolor.org/journal/w2004/5/ (11.12.2018).

9. Талалай М. Г. Российский некрополь в Италии. - М.: Старая Басманная, 2014. - 988 с.

10. Тонини Л. Первые читатели Достоевского в реестрах Кабинета Вессё во Флоренции // Современные проблемы изучения поэтики и биографии Достоевского: Рецепция, вариации, интерпретации / под ред. В. Н. Захарова, К. А. Степаняна, Б. Н. Тихомирова. - СПб., 2016. - С. 329-342. (Dostoevsky Monographs. Vol. 5).

11. Aloe S. Angelo De Gubernatis e il mondo slavo. - Pisa: TEP, 2000. - 316 p.

12. Garzaniti M. La comunità ortodossa russa a Firenze fra Ottocento e Novecento // Annali di Storia di Firenze. - 2013. - Vol. VIII. - Pp. 285-295.

13. Ghini G. Dostoevskij a Bologna: le ragioni di un silenzio // L'Est europeo e l'Italia. Immagini e rapporti culturali. — Genève: Slatkine; Moncalieri: C.I.R.V.I., 1995. — Pp. 339-348.

14. Mascagni R. Dostoevskij a Firenze // Reality. — 2017. — № 86. - Pp. 54-55.

15. Meloni Trkulja S. I Demidoff e la chiesa russa di Firenze // I Demidoff a Firenze e in Toscana / Tonini L. (a cura di). - Firenze: Olschki, 1996. - Pp. 251-260.

16. Strelsky K. Dostoevsky in Florence // The Russian Review. — Vol. 23 - № 2 (Apr., 1964). — Pp. 149-163.

17. Supino V. I soggiorni di Dostoevskij in Europa e la loro influenza sulla sua opera. 2a edizione. - Firenze: LoGisma, 2017. - 136 p.

18. Tonini Steidl L. I soggiorni fiorentini di Fëdor Dostoevskij // Antologia Vieusseux. — 2000. — № $18 .-$ Pp. 27-46.

Для цитирования: Алоэ С. Италия в биографии Ф. М. Достоевского: Несколько вводных заметок по поводу архивных находок Валентины Супино // Неизвестный Достоевский. - 2019. - № 1. - С. 3-9 [Электронный pecypc]. - URL: http:// unknown-dostoevsky.ru/files/redaktor_pdf/1554205909.pdf. DOI: 10.15393/j10.art.2019.3801 


\title{
Stefano Aloe \\ PhD, Associate Professor and Researcher of Russian Literature at the University of Verona, Vice-President of the International Dostoevsky Society \\ (Verona, Italy) \\ stefano.aloe@univr.it
}

\section{Italy in the Biography of F. M. Dostoevsky: Several Introductory Notes About the Archival Finds of Valentina Supino}

\begin{abstract}
The role of Italy in the work and biography of Fedor Dostoevsky is indisputably great, independently of the not so long time that he passed in this country. The writer visited Italy three times (in 1862, 1863 and 1868-69) and each journey took on a specific importance and peculiar meaning in his work and biography. Moreover, since his youth Dostoevsky cultivated ties with Italy: he loved Renaissance painting and the Italian opera, he read about the main figures of the Italian history, the country's political situation and its relation to the religious stances connected with the "holy city" of Rome and the Catholicism. Nonetheless, the links between Dostoevsky and Italy have not yet become a subject of research for a monographic work and therefore his three sojourns in the country hide lots of undetermined aspects. First of all, the present annotations open up a series of questions about the situation of the biographical researches that pertain the Italian period of the writer's life. Secondly, they are an introduction to the subsequent article by Valentina Supino who has discovered new interesting facts about the last writer's stay in Florence.
\end{abstract}

Keywords: Dostoevsky in Italy, Florence, Catholicism and Orthodoxy, Dostoevsky Studies in Italy

\section{REFERENCES}

1. Aloe S. The First Stages of Acquaintance with Dostoevsky in Italy. In: Dostoevskiy i mirovaya kul'tura. Al'manakh № 15 [Dostoevsky and World Culture. Almanac No. 15]. St. Petersburg, 2000, pp. 141-155. (In Russ.)

2. Zakharov V. N. A Judicial Search of Dostoevsky in the Summer of 1871. In: Dostoevskiy $i$ mirovaya kul'tura. Al'manakh № 29 [Dostoevsky and World Culture. Almanac No. 29]. St. Petersburg, 2012, pp. 276-277. (In Russ.)

3. Zakharov V. N. An Unpublished Autograph of Dostoevsky: Dostoevsky and S. P. Koloshin. In: Uchenye zapiski Petrozavodskogo gosudarstvennogo universiteta. Seriya: Obshchestvennye i gumanitarnye nauki [Proceedings of Petrozavodsk State University. Series: Social Sciences and Humanities], 2013, no. 7 (136), vol. 2, pp. 58-61. (In Russ.)

4. Kara-Murza A. A. Znamenitye Russkie o Florentsii [Famous Russians About Florence]. Moscow, Nezavisimaya Gazeta Publ., 2001, pp. 63-82. (In Russ.)

5. Prozhogin N. P. Dostoevsky in Florence. In: Inostrannaya literatura, 1981, no. 8, pp. 237-244. (In Russ.)

6. Prozhogin N. P. Dostoevsky in Florence in 1868-1869. In: Dostoevskiy. Materialy i issledovaniya [Dostoevsky. Materials and Researches]. Leningrad, Nauka Publ., 1983, vol. 5, pp. 204-208. (In Russ.) 
7. Risaliti R. Russkaya Toskana. Stat'i raznykh let o russkikh $v$ Toskane i toskantsakh $v$ Rossii [Russian Tuscany. Articles of Different Years on the Russians in Tuscany and the Tuscans in Russia]. St. Petersburg, Aleteyya Publ., 2011. 192 p. (In Russ.)

8. Talalay M. The Russian Orthodox Church in Florence. In: Rossiya v kraskakh [Russia in Colors]. Winter 2004-2005, no. 1. Available at: http://ricolor.org/journal/w2004/5/ (accessed on December 11, 2018). (In Russ.)

9. Talalay M. G. Rossiyskiy nekropol'v Italii [Russian Necropolis in Italy]. Moscow, Staraya Basmannaya Publ., 2014. 988 p. (In Russ.)

10. Tonini L. The First Readers of Dostoevsky in the Registers of the Cabinetto of Vieusseux in Florence. In: Sovremennye problemy izucheniya poetiki i biografii Dostoevskogo: Receptsiya, variatsii, interpretatsii [Modern Problems of Studying Dostoevsky's Poetics and Biography: Reception, Variations, Interpretations]. St. Petersburg, 2016, pp. 329-342. (In Russ.)

11. Aloe S. Angelo De Gubernatis e il mondo slavo [Angelo De Gubernatis and the Slavic World]. Pisa, TEP Publ., 2000. 316 p. (In Italian)

12. Garzaniti M. La comunità ortodossa russa a Firenze fra Ottocento e Novecento [Russian Orthodox Community in Florence Between the Nineteenth and Twentieth Centuries]. In: Annali di Storia di Firenze, 2013, vol. 8, pp. 285-295. (In Italian)

13. Ghini G. Dostoevskij a Bologna: le ragioni di un silenzio [Dostoevsky in Bologna: The Reasons of a Silence]. In: L'Est europeo e l'Italia. Immagini e rapporti culturali [European East and Italy. Images and Cultural Links]. Genève, Slatkine Publ., Moncalieri, C.I.R.V.I. Publ., 1995, pp. 339-348. (In Italian)

14. Mascagni R. Dostoevskij a Firenze [Dostoevsky in Florence]. In: Reality, 2017, no. 86, pp. 5455. (In Italian)

15. Meloni Trkulja S. I Demidoff e la chiesa russa di Firenze [Demidovs and the Russian Church in Florence]. In: I Demidoff a Firenze e in Toscana [Demidovs in Florence and Tuscany]. Firenze, Olschki Publ., 1996, pp. 251-260. (In Italian)

16. Strelsky K. Dostoevsky in Florence. In: The Russian Review, 1964, vol. 23, no. 2 (April), pp. 149-163. (In English)

17. Supino V. I soggiorni di Dostoevskij in Europa e la loro influenza sulla sua opera [Dostoevsky's Stays in Europe and Their Influence on His Work]. Firenze, LoGisma Publ., 2017. 136 p. (In Italian)

18. Tonini Steidl L. I soggiorni fiorentini di Fëdor Dostoevskij [Florentine Stays of F. Dostoevsky]. In: Antologia Vieusseux, 2000, no. 18, pp. 27-46. (In Italian)

For citation: Aloe S. Italy in the Biography of F. M. Dostoevsky: Several Introductory Notes About the Archival Finds of Valentina Supino. In: The Unknown Dostoevsky, 2019, no. 1, pp. 3-9. Available at: http://unknown-dostoevsky.ru/files/redaktor_pdf/1554205909. pdf. DOI: 10.15393/j10.art.2019.3801

Received: December 28, 2018

Date of publication: March 22, 2019 